\title{
Ewolucja regulacji dotyczącej błędu co do znamion typu podstawowego w polskich kodyfikacjach karnych
}

\author{
JERZY LACHOWSKI \\ Katedra Prawa Karnego i Kryminologii UMK \\ Uniwersytet Mikołaja Kopernika w Toruniu
}

I. Błąd definiowany jest jako mylne wyobrażenie rzeczywistości po stronie sprawcy, to rozbieżność zachodząca pomiędzy rzeczywistością, a jej odzwierciedleniem w psychice człowieka. Trafnie jednak podkreślano w doktrynie prawa karnego, że należy go odróżnić od braku wiedzy ${ }^{1}$. Błąd łączyć trzeba ze świadomością człowieka, jako pewnym przeżyciem psychicznym ${ }^{2}$. Człowiek może mieć bardzo dużą wiedzę, co wcale nie musi oznaczać, że wiedza ta pozostaje w orbicie wspomnianej świadomości ${ }^{3}$. Trudno zatem zgodzić się z K. Buchałą, który twierdził, że błąd jest wynikiem braku wiedzy, wszak nie zawsze tak się dzieje ${ }^{4}$. Autor sam jednak dalej przyznał, że „możemy odpowiednią wiedzę posiadać, jednak na skutek braku aktywności psychicznej (koncentracji uwagi, odszukania wiedzy w pamięci trwałej) nie uświadamiać sobie [...]" pewnych okoliczności ${ }^{5}$. Od błędu konieczne jest również odróżnienie omyłki, którą postrzega się jako akt niezgodny $\mathrm{z}$ intencją podmiotu ${ }^{6}$.

Problematyka błędu co do faktu jest jedną z bardziej skomplikowanych w obszarze prawa karnego, albowiem skupia ona podstawowe zagadnienia związane z pociąganiem do odpowiedzialności karnej. Przede wszystkim wiąże się nierozerwalnie z problematyką winy i jej postrzeganiem. Sposób ujęcia winy w sensie teoretycznym ma wpływ na funkcje błędu i jego ulokowanie w strukturze

\footnotetext{
1 Tak np. W. Wolter, Funkcja błędu w prawie karnym, Warszawa 1965, s. 9.

2 Ibidem.

3 Ibidem.

${ }^{4}$ K. Buchała, Prawo karne materialne, Warszawa 1980, s. 370.

5 Ibidem.

${ }^{6}$ Por. W. Wolter, op. cit., s. 11-12; K. Buchała, op. cit., s. 370.
} 
przestępstwa. Zagadnienie błędu co do faktu dotyka także problematyki związku przyczynowego, zwłaszcza w przypadku gdy do przebiegu związku przyczynowego włącza się causa, której sprawca nie przewidział, choć mógł to przewidzieć. Związek zagadnienia błędu z problematyką zasad odpowiedzialności karnej powoduje, że jest to konstrukcja wciąż bardzo atrakcyjna, której warto przyjrzeć się bliżej. Wgląd w to zagadnienie jest jeszcze bardziej uzasadniony, gdy zwróci się uwagę na to, że uregulowanie dotyczące błędu, zawarte w art. $28 \S 1$ k.k., ostatnimi czasy poddane zostało pewnym zmianom. Jakkolwiek było ono niedawno nawet przedmiotem opracowania monograficznego ${ }^{7}$ czy też artykułowego już po noweli z 20 lutego $2015 \mathrm{r}^{8}$, to nie można z całą pewnością stwierdzić, że wszystko w tej materii zostało już dostatecznie naświetlone w sposób, który wyklucza jakąkolwiek dalszą dyskusję. Stało się wręcz odwrotnie - nowy kształt art. 28 $\S 1$ k.k., a także ostatnie opracowania, które mają za przedmiot tę regulację, inspirują do dalszych badań nad rzeczoną problematyką i skłaniają do pewnych polemik oraz formułowania postulatów de lege ferenda. Ambicją piszącego te słowa nie jest oczywiście kompleksowa analiza problematyki błędu co do faktu, wszak podjęcie się takiego zadania w niedużym opracowaniu artykułowym z góry skazane byłoby na niepowodzenie. Natomiast wydaje się, że warto zwrócić uwagę na jedynie kilka kwestii związanych z problematyką błędu co do faktu w ujęciu ewolucyjnym art. $28 \S 1$ k.k., w tym na funkcję tej instytucji de lege lata oraz poprawność jej ujęcia w rzeczonym przepisie w brzmieniu aktualnie obowiązującym. Tym zagadnieniom poświęcone zostaną dalsze rozważania. Poza zakresem niniejszego opracowania pozostawiono zagadnienia odnoszące się do błędu co do znamienia kwalifikującego lub uprzywilejowującego. Zasadniczo błąd taki nie wyłącza odpowiedzialności za przestępstwo umyślne, wpływa natomiast na modyfikację odpowiedzialności karnej.

II. Zagadnienie błędu co do faktu było uregulowane w art. 20 § 1 k.k. z 1932 r. Zgodnie z tym przepisem nie popełniał przestępstwa ten, kto dopuszczał się czynu pod wpływem błędu co do okoliczności należącej do istoty czynu, z wyjątkiem gdy chodzi o występek nieumyślny, a błąd był wynikiem nieostrożności lub niedbalstwa. Analizując rzeczone uregulowanie, nie sposób nie zauważyć, że ustawodawca użył tutaj dwóch sformułowań, które mogą rodzić pewne wątpliwości. Po pierwsze, wskazać trzeba pojęcie istoty czynu. Prima facie wydawać się może, że jest ono dość szerokie i wykracza poza ustawowe znamiona. Nie posłużono się w tym przypadku sformułowaniem choćby istoty czynu zabronionego, co mogło

7 Por. Ł. Pohl, Bład co do okoliczności stanowiacej znamię czynu zabronionego w polskim prawie karnym (Zagadnienia ogólne), Poznań 2013.

8 M. Małecki, Usprawiedliwiony błąd co do okoliczności stanowiącej znamię czynu zabronionego w świetle nowelizacji art. 28 \& $1 \mathrm{kk}$, CzPKiNP 2015, nr 1. 
rodzić refleksję, że istota ta to nie tylko zespół ustawowych znamion, lecz także istota czynu jako takiego, który stanowi podstawę prawnokarnego wartościowania. W uzasadnieniu projektu kodeksu karnego z 1932 r. czytamy, że istota czynu

obejmuje cały szereg wypadków błędu faktycznego, a zatem działanie przeciwko człowiekowi, w przekonaniu, że jest zwierzęciem lub przedmiotem nieożywionym, działanie polegające na zaborze cudzej rzeczy ruchomej w przekonaniu, że jest własną, działanie przeciwko człowiekowi bez zdawania sobie sprawy, że posiada on w stosunku do sprawcy swoiste właściwości (np. osoba zwierzchnicza), działanie w przekonaniu, że nikomu nie grozi żadne niebezpieczeństwo, pomimo że niebezpieczeństwo to zachodzi. Formuła ta obejmować może nawet błąd co do istnienia stosunku prawnego (zawarcia związku małżeńskiego z osobą, o której sprawca mylnie sądzi, iż nie pozostaje w żadnym związku małżeńskim) ${ }^{9}$.

Jak podawano w motywach legislacyjnych, w wymienionych przypadkach miała zachodzić nieświadomość lub błąd co do okoliczności faktycznej. To musi nasuwać spostrzeżenie, że odróżniano od siebie te dwa stany ${ }^{10}$. Nie dochodziło tutaj jednak automatycznie do wyłączenia odpowiedzialności karnej, wszak jak podkreślano, zależało to od oceny sędziego, który badał, czy sprawca miał możliwość zorientować się, że rzeczywistość jest inna od tej wyobrażonej ${ }^{11}$. Również J. Makarewicz podkreślał, że błąd co do istoty czynu oznacza błąd co do przedmiotu, błąd co do właściwości przedmiotu, co do właściwości sytuacji, w której znalazł się sprawca ${ }^{12}$. Na gruncie kodeksu karnego z 1932 r. w literaturze zaliczano do istoty czynu także okoliczność wyłączającą bezprawność czynu, taką jak obrona konieczna, co było wyrazem sympatyzowania z teorią negatywnych znamion ${ }^{13}$. Wskazane rozumienie istoty czynu musi prowadzić do wniosku, że pojęcie to utożsamiano $\mathrm{w}$ istocie ze znamionami typu ${ }^{14}$.

Na gruncie przepisu art. $20 \S 1$ k.k. z 1932 r. jakkolwiek rozróżniano nieświadomość i błąd, to jednak twierdzono, że nie ma między nimi żadnej różnicy. Jak podkreśla L. Peiper, nieświadomość zachodzi, gdy sprawca czegoś w ogóle nie wie, natomiast błąd wchodzi w grę, jeśli wiedza sprawcy, a także wyobrażenia o otaczającej go rzeczywistości są niezupełne, całkowicie błędne, częściowo nietrafne. Autor podniósł, że „błędna wiadomość lub wyobrażenie o czymś jest

${ }^{9}$ Fragmenty uzasadnienia przytoczone za L. Peiperem - Komentarz do kodeksu karnego, prawa o wykroczeniach, i przepisów wprowadzajacych wraz z niektóremi ustawami dodatkowemi i wzorami orzeczeń do prawa o wykroczeniach, Kraków 1933, s. 100.

10 Ibidem.

11 Uzasadnienie projektu za ibidem.

12 Por. J. Makarewicz, Kodeks karny. Komentarz, Lwów 1938, s. 98.

13 Ibidem.

14 Zob. W. Wolter, op. cit., s. 36-37; por. też Z. Ćwiąkalski, Błąd w prawie karnym - stan obecny i proponowane zmiany, [w:] Problemy reformy prawa karnego, red. T. Bojarski, E. Skrętowicz, Lublin 1993, s. 176. 
więc właściwie nieświadomością prawdziwego stanu rzeczy"15. Nie było zatem zasadne czynienie różnicy między nimi.

Kodeks karny z 1932 r. stanął na stanowisku psychologicznej koncepcji winy, traktując błąd co do faktu jako okoliczność, która ją wyłącza. Za winę uważano zatem sam stosunek psychiczny sprawcy do czynu. Stosunek ten mógł polegać albo na tym, że sprawca chciał popełnić przestępstwo, albo możliwość skutku przestępnego lub przestępność działania przewidywał i się na to godził (art. 14 $\S 1$ k.k. z 1932 r.) W tym przypadku mówiono o winie umyślnej. W doktrynie przyjmowano, że skoro przepis art. $14 \S 1$ k.k. z 1932 r. wymagał dla przypisania winy umyślnej tzw. złego zamiaru albo woli popełnienia przestępstwa, ewentualnie przynajmniej zgody na przestępny charakter czynu, to w warunkach błędu nie sposób było przypisać czy to owego złego zamiaru, woli, czy też zgody na przestępność czynu. Nie było zatem możliwe przypisanie winy umyślnej ${ }^{16}$.

Błąd mógł natomiast implikować odpowiedzialność za przestępstwo nieumyślne, które - jak podkreślano — polegało na nieświadomości bezprawności czynu zabronionego ${ }^{17}$. Wydaje się, że konstatacja ta nie jest do końca poprawna, albowiem trzeba zwrócić uwagę na to, że kodeks karny z 1932 r. ujmował winę nieumyślną jako lekkomyślność i niedbalstwo (art. 14 § 2 k.k. z 1932 r.). Ta pierwsza postać polegała na tym, że sprawca przewidywał możliwość skutku przestępnego, lecz bezpodstawnie przypuszczał, że tego uniknie, a ta druga na tym, że skutku przestępnego nie przewidywał, choć może lub powinien przewidzieć. Jeśli przy lekkomyślności sprawca przewidywał nastąpienie skutku przestępnego, lecz bezpodstawnie przypuszczał, że tego uniknie, to owo przewidywanie czynu oznaczało świadomość bezprawności. Przewidywać pewien stan rzeczy objęty ustawowymi znamionami czynu zabronionego to nic innego, jak mieć świadomość, że taki stan rzeczy jest zabroniony pod groźbą kary, a to nie mniej, nie więcej jak świadomość bezprawności. Zatem w przypadku lekkomyślności nie zachodziła nieświadomość bezprawności. Inaczej było w przypadku niedbalstwa, gdzie sprawca popełnienia czynu lub skutku przestępnego nie przewidywał. Brak przewidywania popełnienia czynu czy skutku przestępnego oznaczać musiał brak świadomości bezprawności takiego czynu.

Odpowiedzialność karna za występek nieumyślny na gruncie art. 20 § k.k. z 1932 r. wchodziła w grę jedynie wówczas, gdy błąd był wynikiem nieostrożności lub niedbalstwa. O ile pojęcie niedbalstwa dało się rekonstruować na podstawie art. $14 \S 2$ k.k. z 1932 r. in fine, o tyle gorzej było w przypadku pojęcia nieostrożności. Na tym odcinku treść art. 20 § 1 k.k. z 1932 r. rozminęła się z art. 14 § k.k. z 1932 r. w zakresie ujęcia lekkomyślności. Ustawodawca nie zdefiniował go w żaden sposób. Nie nawiązywał tym samym bezpośrednio do pojęcia lekkomyślności,

15 L. Peiper, op. cit., s. 101.

16 Ibidem, s. 99.

17 J. Makarewicz, op. cit., s. 97; L. Peiper, op. cit., s. 101. 
które scharakteryzowano w art. 14 § 2 k.k. z 1932 r. Z uregulowania wynikało, że pomiędzy nieostrożnością lub niedbalstwem charakteryzującym zachowanie sprawcy a błędnym postrzeganiem rzeczywistości objętej znamionami czynu zabronionego musiał zachodzić związek. Jakkolwiek w art. 20 § 1 k.k. z 1932 r. posłużono się pojęciem nieostrożności, które nie zostało wyjaśnione w art. 14 § 2 k.k. z 1932 r., to jednak z tym właśnie uregulowaniem wiązano odpowiedzialność za występek nieumyślny w przypadku opisanym w art. 20 § 1 k.k. z 1932 r., albowiem — jak podkreślono - skoro sprawca ponosił odpowiedzialność za nieostrożne lub niedbałe zachowanie w myśl art. $14 \S 2$ k.k. z 1932 r., to nie było podstawy aby uwalniać go od odpowiedzialności karnej w przypadku, gdy takiego rodzaju zachowanie wywołało jego błąd ${ }^{18}$.

W kodeksie karnym z 1969 r. błąd co do faktu uregulowano w art. 24 § 1 k.k., zgodnie z którym nie popełniał przestępstwa sprawca, który dopuszczał się czynu pod wpływem błędu co do znamion czynu zabronionego, z wyjątkiem gdy chodzi o występek nieumyślny, a błąd był wynikiem lekkomyślności lub niedbalstwa. Usunięto niejasne sformułowanie z uregulowania dotyczącego błędu w postaci nieostrożności jako jego przyczyny, zastąpiono je pojęciem lekkomyślności ${ }^{19}$. Pojęcie niedbalstwa pozostało w przepisie o błędzie niezmienione, choć wypełniono je nieco inną treścią, podobnie zresztą jak lekkomyślność. Zgodnie z art. 7 § 2 k.k. przestępstwo nieumyślne zachodziło zarówno wówczas, gdy sprawca przewiduje możliwość popełnienia czynu zabronionego, choć bezpodstawnie przypuszcza, że tego uniknie, jak i wtedy, gdy możliwości takiej nie przewiduje, choć powinien i może przewidzieć. Taka stylizacja nakazywała rozróżnić błąd zawiniony od błędu niezawinionego. W literaturze podnoszono, że błąd zawiniony to błąd, z powodu którego można było sprawcy uczynić zarzut lekkomyślności lub niedbalstwa w rozumieniu art. $7 \S 2$ k.k. ${ }^{20}$

W doktrynie prawa karnego dostrzegano odmienność sformułowania zawartego w art. 24 § 1 k.k. z 1969 r. in fine oraz art. 7 § 2 k.k. z 1969 r. ${ }^{21} \mathrm{~W}$ tym pierwszym postanowiono, że odpowiedzialność karna nie była wyłączona w przypadku występku nieumyślnego, jeśli błąd (a nie czyn zabroniony) był wynikiem lekkomyślności lub niedbalstwa, natomiast przepis art. 7 § 2 k.k. z 1969 r. wskazywał istotę przestępstwa popełnionego nieumyślnie, odnosił zatem lekkomyślność i niedbalstwo do czynu zabronionego stypizowanego w ustawie. Podnoszono, że taka stylizacja stanowi ukłon $\mathrm{w}$ kierunku tradycji i ma być rozumiana zgodnie $\mathrm{z}$ art. 7 $\S 2$ k.k. z 1969 r. ${ }^{22}$

18 L. Peiper, op. cit., s. 102.

19 W doktrynie podnoszono, że unormowanie zawarte w art. 24 § 1 k.k. z 1969 r. było bardziej precyzyjne. Zob. Z. Ćwiąkalski, op. cit., s. 177.

20 Por. np. K. Buchała, op. cit., s. 370.

21 Zob. ibidem, s. 372.

22 Ibidem. 
Zasadniczo błąd co do okoliczności faktycznej, opisany w art. $24 \S 1$ k.k. z 1969 r., uchylał również odpowiedzialność karną za przestępstwo umyślne $e^{23}$. Taki wniosek nasuwało sformułowanie tego uregulowania in fine, gdzie znajduje się zastrzeżenie, że błąd co do ustawowych znamion czynu zabronionego zasadniczo uchyla przestępność czynu z wyjątkiem sytuacji, gdy idzie o występek nieumyślny. Błąd taki nie wykluczał zatem odpowiedzialności za przestępstwo nieumyślne pod warunkiem oczywiście, że ustawa taką odmianę rodzajową przewidywała. Warto jednak w tym miejscu odnotować pogląd M. Cieślaka, który stwierdzał, że błąd wyłączał te formy winy, które były oparte na świadomości, a więc również lekkomyślność 24 .

Nie zawsze jednak błąd wyłączał odpowiedzialność karną za przestępstwo umyślne. W niektórych porządkach prawnych błąd co do znamion czynu zabronionego mógł wpływać na odpowiedzialność karną tylko wówczas, gdy był nie do uniknięcia (invinicble) albo był uzasadniony ${ }^{25}$. Jeśli taka sytuacja nie zachodziła, błąd nie wyłączał odpowiedzialności nawet za przestępstwo umyślne. W prawie anglosaskim wyróżnia się tzw. strict liability, która wchodzi w grę w przypadku drobniejszych czynów zabronionych. W tym wypadku dla odpowiedzialności karnej nie mają znaczenia zjawiska psychiczne zachodzące po stronie sprawcy, lecz sam tylko czyn. Wydawać by się mogło, że skoro w przypadku takich czynów zjawiska psychiczne nie mają żadnego znaczenia, to również błąd nie będzie miał doniosłości prawnej, skoro lokuje się go w psychice sprawcy. Tymczasem w angielskim prawie karnym i w przypadku takich czynów nie wyklucza się błędu jako okoliczności usprawiedliwiającej, o ile tylko błąd był uzasadniony (reasonable), co oceniano według kryteriów obiektywnych. Takie stanowisko zarysowało się w orzecznictwie angielskim po drugiej wojnie światowej ${ }^{26}$.

Stwierdzenie, że błąd co do faktu wyłączał odpowiedzialność za przestępstwo umyślne nie jest do końca ścisłe, albowiem błąd taki nie wyłączał winy umyślnej w przypadku gdy sprawca błądził co do okoliczności kwalifikującej lub uprzywilejowującej typ czynu zabronionego. W takich sytuacjach sprawca miał zamiar zrealizowania czynności czasownikowej oraz zaatakowania określonego przedmiotu, tyle że błądził co do cech szczególnych takiego obiektu lub okoliczności popełnienia czynu. Uzasadniało to odpowiedzialność karą za przestępstwo z winy umyślnej, lecz w typie podstawowym. Trafnie zatem podkreślał I. Andrejew, że czyn zabroniony popełniony w warunkach błędu może nie być przestępstwem,

${ }^{23}$ Funkcja błędu co do faktu w postaci wyłączenia zamiaru była dostrzega również w literaturze zagranicznej. Zob. poglądy przywołane przez I. Andrejewa, Unormowanie błędu we wspótczesnym prawie karnym, PiP 1979, nr 5, s. 39-40.

24 M. Cieślak, Polskie prawo karne. Zarys systemowego ujęcia, Warszawa 1990, s. 338.

25 Zob. ibidem, s. 40-41.

26 Ibidem, s. 41; zob. też A. Jaskuła, Uregulowanie błędu co do znamion typu czynu zabronionego w prawie karnym Polski i wybranych krajów europejskich, CzPKiNP 1999, nr 2, s. 165. 
może być innym przestępstwem umyślnym albo przestępstwem nieumyślnym, „W każdym razie nie jest tym przestępstwem umyślnym, którego błąd dotyczy”27. Ściślej ujmując, czyn taki nie będzie tą odmianą rodzajową przestępstwa umyślnego, którego błąd dotyczy.

W doktrynie prawa karnego podkreślano, że błąd wyłączał odpowiedzialność karną, o ile był błędem istotnym, tj. dotyczył okoliczności należącej do znamion czynu zabronionego ${ }^{28}$. Teza taka była jednak co najmniej nieścisła, albowiem nie każdy błąd dotyczący okoliczności należącej do znamion czynu zabronionego jest błędem istotnym. Do błędów nieistotnych odnoszących się do znamion czynu zabronionego należy error in personam i error in obiecto, o ile dotyczą przedmiotów korzystających z identycznej ochrony prawnej (np. zabicie osoby A zamiast osoby B, zabór rzeczy na szkodę osoby A zamiast na szkodę osoby B, zabór rzeczy X zamiast rzeczy Y). Stąd należy podnieść, że błędem istotnym co do okoliczności należącej do znamion czynu zabronionego jest tylko taki błąd, którego przedmiot odnosi się do obiektów korzystających z ochrony prawnokarnej o różnej intensywności.

W nauce prawa karnego podnoszono, że każde przestępstwo nieumyślne wiąże się z błędem co do ustawowego znamienia czynu zabronionego. Wskazywano, iż przy lekkomyślności błąd ten polega na tym, że sprawca, przewidując możliwość popełnienia czynu zabronionego, liczy na to, że go nie popełni, podczas gdy rzeczywistość jest odmienna (dochodzi do popełnienia czynu) ${ }^{29}$. Z kolei w przypadku niedbalstwa - jak podnoszono - błąd polegać miał na tym, że sprawca nie przewiduje możliwości popełnienia czynu zabronionego, choć w rzeczywistości dochodziło do niego ${ }^{30}$. Podkreślano jednocześnie, że błąd taki nie przesądza jeszcze odpowiedzialności za przestępstwo nieumyślne, albowiem konieczne jest ustalenie, że sprawca mógł błędu uniknąć, a zatem błąd taki musi być zawiniony ${ }^{31}$.

Powstaje pytanie, czy istotnie w przypadku przestępstwa nieumyślnego zachodził błąd co do znamion czynu zabronionego. Aby tę kwestię rozstrzygnąć, należy przypomnieć jeszcze raz, na czym polegały lekkomyślność i niedbalstwo w świetle art. 7 § 2 k.k. z 1969 r. Otóż w przypadku lekkomyślności sprawca przewidywał możliwość popełnienia czynu zabronionego, lecz bezpodstawnie przypuszczał, że tego uniknie. Ustawowe znamiona czynu zabronionego znajdowały zatem prawidłowe odbicie w psychice sprawcy, a jego błąd sprowadzał się jedynie do oceny tego, czy uda się przestępstwa uniknąć, czy też nie, mimo sprowadzenia

27 I. Andrejew, Polskie prawo karne w zarysie, Warszawa 1980, s. 151; por. też J. Bafia, Polskie prawo karne, Warszawa 1989, s. 178.

28 Tak np. I. Andrejew, Polskie prawo karne..., s. 151.

29 W. Wolter, Nauka o przestępstwie. Analiza prawnicza na podstawie przepisów części ogólnej kodeksu karnego z 1969 r., Warszawa 1973, s. 229.

30 Ibidem.

31 Ibidem, s. 230. 
ryzyka jego popełnienia. Prima facie można zatem powiedzieć, że w przypadku lekkomyślności błąd nie dotyczył ustawowych znamion czynu zabronionego, lecz prawdopodobieństwa jego popełnienia. Jeśli przypuszczenie, że sprawca czynu nie popełni, mimo jego przewidywania, było zasadne, to jednocześnie oznaczało, że sprawca niezasadnie przewidywał popełnienie czynu zabronionego. Skoro sprawca niezasadnie przewidywał popełnienie czynu zabronionego, to oznaczało, że jego przypuszczenie, iż czynu uniknie, było uprawnione, co wykluczało możliwość przypisania winy nieumyślnej w postaci lekkomyślności. Jeżeli natomiast sprawca przewidywał popełnienie czynu zabronionego, lecz jednocześnie niezasadnie liczył się z tym, że czynu zabronionego uniknie, to możliwe było przypisanie przestępstwa nieumyślnego w postaci lekkomyślnej, o ile ustawa takie przestępstwo przewiduje. Wydawać się może zatem, że w przypadku lekkomyślności błąd lokował się na nieco innej płaszczyźnie niż rzeczywistość wyznaczona znamionami wyraźnie określonymi w ustawie, mianowicie na płaszczyźnie oceny prawdopodobieństwa popełnienia czynu.

Inaczej sytuacja kształtowała się w przypadku niedbalstwa. Tutaj w świadomości sprawcy znamiona ustawowe czynu zabronionego w ogóle nie znajdują odzwierciedlenia. Sprawca nie miał świadomości, że popełnienia czyn zabroniony. Wręcz przeciwnie - był przekonany, że popełnienia czyn irrelewantny z punktu widzenia prawa karnego, w pełni legalny. Jego błąd polega zatem na nieświadomości realizacji ustawowych znamion czynu zabronionego in genere i nie odnosi się do określonego znamienia.

III. W trakcie prac nad projektem nowego kodeksu karnego przyjęto, że błąd co do znamion czynu zabronionego dotyczy jedynie błędu w postaci nieświadomości znamion pozytywnych i urojenia znamienia negatywnego, nie odnosi się natomiast do urojenia znamienia pozytywnego, co należało oceniać przez pryzmat instytucji usiłowania nieudolnego. W toku prac Komisji ds. Reformy Prawa Karnego w 1990 r. zaproponowano m.in. następujące brzmienie tego uregulowania: ,art. 27. Nie popełnia przestępstwa umyślnego, kto dopuszcza się czynu pod wpływem błędu co do okoliczności stanowiącej znamię czynu zabronionego" 32 . Przyjęto jednocześnie, że skoro błąd co do znamion czynu zabronionego leży u podstaw zasadniczo każdego przestępstwa nieumyślnego, regulację skutków takiego błędu pozostawiono w przepisie określającym czyn zabroniony popełniony nieumyślnie. Tym samym uniknięto powielania tych samych sformułowań w przepisie określającym czyn popełniony nieumyślnie oraz w uregulowaniu odnoszącym się do skutków błędu co do okoliczności stanowiącej znamię czynu

32 Tekst projektu przytoczony za P. Kardasem, Regulacja błędu w projekcie kodeksu karnego, PS 1992, nr 1, s. 72; zob. również P. Kardas, M. Rodzynkiewicz, Projekt kodeksu karnego w świetle opinii sędziów i prokuratorów (część druga - wyłączenie odpowiedzialności karnej), WPP 1995, nr 3-4, s. 37. 
zabronionego ${ }^{33}$. Uniknięto również niezręcznego sformułowania, że błąd był wynikiem lekkomyślności lub niedbalstwa.

Kodeks karny z 1997 r. stanął na stanowisku czystej teorii normatywnej winy, co jednoznacznie wynika z uzasadnienia projektu tego aktu. W ramach pojęcia winy, w tym ujęciu, umyślność i nieumyślność przesuwa się do znamion czynu zabronionego, na skutek czego nie wyodrębnia się już winy umyślnej lub nieumyślnej. Wina staje się pojęciem jednolitym, a jej istota sprowadza się do zarzutu stawianego sprawcy z powodu nieakceptowalnego przez porządek prawny zachowania $^{34}$. Takie podejście do problemu relacji między stroną podmiotową czynu zabronionego (umyślnością i nieumyślnością) a winą musiało mieć wpływ na uregulowanie odnoszące się do zagadnienia błędu co do znamion czynu zabronionego. W uzasadnieniu do projektu k.k. podano, że unormowanie zawarte w art. 28 $\S 1$ k.k. nie odbiega w sensie merytorycznym od poprzedniej regulacji kodeksowej, z czym nie do końca można się zgodzić, wszak błąd taki miał wyłączać popełnienie umyślnego czynu zabronionego, co miało być jego wyłączną funkcją, a nie winę umyślną. W uzasadnieniu podkreślano, że zagadnienie odpowiedzialności za przestępstwa nieumyślne poddano regulacji zawartej w art. 8 k.k. i art. 9 § 2 k.k., dzięki czemu uniknięto powtórzeń, z którymi mieliśmy do czynienia w kodeksie karnym z 1969 r. w art. 7 § k.k. i art. $24 \S 1$ k.k. ${ }^{35}$

Uwzględniając czystą teorię normatywną winy oddzielającą stronę podmiotową czynu zabronionego od winy, przepis o błędzie co do faktu brzmiał pierwotnie tak: „Nie popełnienia umyślnie czynu zabronionego sprawca, który pozostaje w błędzie co do okoliczności stanowiącej jego znamię". Jak podkreślano, błąd w postaci nieświadomości znamienia pozytywnego lub urojenia znamienia negatywnego wyłączał możliwość przypisania zamiaru (a nie winy), albowiem świadomość wszystkich znamion jest przesłanką jego powstania. Zamiar był wyłączony niezależnie od tego, czy taka nieświadomość lub urojenie były zawinione, czy też $n^{3}{ }^{36}$. Natomiast odpowiedzialność za nieumyślny czyn zabroniony była uwarunkowana wypełnieniem przesłanek przypisania nieumyślnego czynu zabronionego, które wskazano w art. 9 \$ 2 k.k. ${ }^{37}$ Przy takim ujęciu trudno odrzucić stwierdzenie, że błąd nie wyłącza winy, lecz dekompletuje ustawowe znamiona umyślnego czynu zabronionego. I taka miała być jego funkcja na gruncie kodeksu karnego z $1997 \mathrm{r}$.

33 P. Kardas, op. cit., s. 73; P. Kardas, M. Rodzynkiewicz, op. cit., s. 37.

34 Zob. fragmenty uzasadnienia projektu kodeksu karnego przytoczone przez A. Wąska, Kodeks karny. Częśś ogólna, t. I, Gdańsk 1999, s. 15.

35 Fragmenty uzasadnienia projektu kodeksu karnego z 1997 r. przytoczone za ibidem, s. 360.

36 Tak np. A. Zoll, Regulacja błędu w projekcie kodeksu karnego, [w:] Problemy nauk penalnych. Prace ofiarowane Pani Profesor Oktawii Górniok, red. L. Tyszkiewicz, Katowice 1996, s. 243-245; idem [w:] Kodeks karny. Część ogólna. Tom I. Komentarz do art. 1-116, red. A. Zoll, W. Wróbel, Warszawa 2016, s. 505; J. Giezek [w:] Kodeks karny. Część ogólna. Komentarz, red. J. Giezek, Warszawa 2007, s. 245.

37 Zob. J. Giezek, op. cit., s. 247. 
Jeszcze przed uchwaleniem nowego kodeksu karnego, w trakcie dyskusji nad jego projektem podnoszono jednak, że przepis art. $28 \S 1$ k.k. stanowiący o niepopełnieniu umyślnie czynu zabronionego $\mathrm{w}$ razie błędu co do okoliczności stanowiącej jego znamię jest w zasadzie zbędny, wszak wynika z niego dokładnie to samo, co z projektowanego art. 9 § 1 k.k. ${ }^{38}$ Niedługo po wejściu w życie kodeksu karnego z 1997 r. — nie bez racji — wskazywano na to samo, a mianowicie że przepis art. $28 \S 1$ k.k. jest w zasadzie niepotrzebny, gdyż to, o czym stanowi, wynika wprost z art. 9 § 1 i 2 k.k., a o utrzymaniu regulacji dotyczącej błędu co do faktu zdecydowała znowu tradycja ustawodawcza ${ }^{39}$.

W nauce podkreśla się, że brak możliwości przypisania świadomości sprawcy pozostającemu w błędzie co do znamion czynu zabronionego oznacza nie tylko niedopuszczalność przypisania zamiaru, lecz również nieumyślności świadomej, która przecież na takiej świadomości jest oparta ${ }^{40}$. Oznaczałoby to, że błąd co do znamion czynu zabronionego dekompletuje nie tylko czyn umyślny, lecz także oparty na nieumyślności świadomej. Nie wydaje się zatem w pełni uprawniona teza, zgodnie z którą błąd co do takich znamion wyłącza odpowiedzialność karną za przestępstwo umyślne, natomiast pozostawia otwartą kwestię odpowiedzialności za przestępstwo nieumyślne, o ile ustawa taki czyn przewiduje, a błąd był zawiniony. Musiałoby to oznaczać, że w razie nieświadomości ustawowych znamion pozytywnych typu zasadniczego albo urojenia znamienia negatywnego dopuszczalne będzie jedynie przypisanie przestępstwa opartego na nieumyślności nieświadomej, wszak tutaj nie zachodzi świadomość charakteryzująca umyślność i nieumyślność świadomą.

Trzeba jednak zwrócić uwagę na to, że nieumyślność świadoma nie wyczerpuje się w braku zamiaru popełnienia czynu zabronionego (a więc w braku woli popełnienia czynu zabronionego), nie wyczerpuje się ona również w samym przewidywaniu popełnienia takiego czynu. W przeciwnym wypadku nie byłoby żadnej różnicy pomiędzy nią a zamiarem bezpośrednim czy ewentualnym, w przypadku których takie przewidywanie również zachodzi ${ }^{41}$. Wydaje się, że przestrzeń pomiędzy godzeniem charakteryzującym zamiar ewentualny a samym przewidywaniem charakteryzującym nieumyślność świadomą należy dopełnić odmiennym ukierunkowaniem woli niż przy zamiarze popełnienia czynu zabronionego ${ }^{42}$. Trzeba odnotować wyrażony w literaturze pogląd, zgodnie z którym dla nieumyśl-

38 P. Kardas, M. Rodzynkiewicz, op. cit., s. 37.

39 A. Wąsek, op. cit., s. 361.

40 Ł. Pohl, op. cit., s. 153.

$41 \mathrm{~W}$ przypadku zamiaru ewentualnego przewidywanie jest wprost wypowiedziane, natomiast w sytuacji zamiaru bezpośredniego daje się wyinterpretować z istoty słowa „chcieć”, które zakłada przewidywanie możliwości popełnienia czynu zabronionego. Ten bowiem, kto chce popełnić czyn zabroniony, musi przewidywać jego popełnienie.

42 Przy zamiarze ewentualnym wola ukierunkowana jest na czyn zabroniony, a przy nieumyślności świadomej — „od czynu zabronionego”. 
ności świadomej ważne jest istnienie zamiaru bezpośredniego niepopełnienia czynu zabronionego, albowiem gdyby przyjąć, że nieumyślność świadomą charakteryzuje godzenie się na uniknięcie czynu zabronionego, które rozumieć można również jako godzenie się na jego popełnienie, to między zamiarem ewentualnym a taką nieumyślnością nie zachodziłaby żadna różnica ${ }^{43}$. Pogląd ten jest jednak dyskusyjny, wszak pomiędzy godzeniem się na popełnienie czynu zabronionego a chęcią jego uniknięcia jest wiele stanów pośrednich, które nie będą mieściły się w woli popełnienia czynu zabronionego i z natury rzeczy będą przesuwały ocenę w kierunku nieumyślności świadomej. Dlatego trafniejsze jest stanowisko, zgodnie z którym w przypadku nieumyślności świadomej zachodzi błędna prognoza co do przebiegu danego zdarzenia, zakładająca istnienie po stronie sprawcy przypuszczenia, że czynu uniknie, przypuszczenia, które może mieć różne odcienie i przejawiać się w woli uniknięcia czynu zabronionego, lecz również w samym braniu pod uwagę tego, że czynu się uniknie ${ }^{44}$. Nie wydaje się trafne utożsamianie godzenia się na popełnienie czynu zabronionego z godzeniem się na jego niepopełnienie, wszak zasadnie można twierdzić, że w obydwu przypadkach wola sprawcy jest odmiennie ukierunkowana.

Jeśli sprawca błędnie prognozuje popełnienie czynu zabronionego, mimo tego, że je przewiduje, to oczywiście zachodzi tutaj błąd, rodzi się jednak wątpliwość czy dotyka on znamion czynu zabronionego, skoro przewiduje możliwość jego popełnienia, a zatem uświadamia sobie jego elementy. Wypada podnieść, że błędna prognoza charakteryzująca nieumyślność świadomą jest wynikiem błędnej oceny prawdopodobieństwa nastąpienia określonego skutku charakteryzującego czyn nieumyślny. Sprawca przypuszcza, że czynu takiego uniknie, dlatego że wadliwie ocenia prawdopodobieństwo sprowadzenia skutku, a wadliwość taka może wynikać z różnych przyczyn, takich jak na przykład brak wiedzy, brak należytej koncentracji uwagi, stan umysłu ${ }^{45}$. Prawdopodobieństwo nastąpienia określonego skutku zdeterminowanie jest z kolei powiązaniem kauzalnym pomiędzy zachowaniem sprawcy a skutkiem, który następuje ${ }^{46}$. Jeśli zatem sprawca błędnie prognozuje przebieg zdarzenia, to oznacza, że błędnie ocenia przebieg przyczynowy między swoim zachowaniem a skutkiem ${ }^{47}$. To wskazuje, że w przypadku nie-

43 Tak J. Giezek, Świadomość sprawcy czynu zabronionego, Warszawa 2013, s. 204.

44 Zob. T. Kaczmarek, J. Giezek, Niektóre problemy nieumyślności, [w:] Rozważania o przestęstwie i karze. Wybór prac z okresu 50-lecia naukowej twórczości. Tom 2. Lata 2006-2015, Wrocław 2016, s. 242.

45 Ibidem.

46 Ibidem.

47 Na gruncie kodeksu karnego z 1932 r. W. Mącior (Problem przestępstw nieumyślnych na tle aktualnych wymagań teorii i praktyki, Kraków 1968, s. 69), analizując różnice zachodzące pomiędzy przewidywaniem charakteryzującym zamiar ewentualny oraz lekkomyślność, stwierdza, że rozróżnienie tych konstrukcji przebiega na poziomie uświadomienia sobie przebiegu związku przyczynowego. 
umyślności świadomej sprawca błądzi co do przebiegu związku przyczynowego ${ }^{48}$. Skoro związek przyczynowy należy do znamion ustawowych czynu zabronionego nieumyślnego (a przecież wszystkie przestępstwa nieumyślne mają charakter materialny), znaczy to, że w takiej sytuacji sprawca również błądzi co do znamion czynu zabronionego. Tym samym nie do końca ma rację $€$. Pohl, który stwierdza, że w przypadku nieświadomości ustawowego znamienia czynu zabronionego nie ma podstaw do przypisania sprawcy również przestępstwa opartego na nieumyślności świadomej49. Jeżeli sprawca przewiduje możliwość popełnienia czynu zabronionego, lecz błądzi co do przebiegu związku przyczynowego, to również pozostaje w błędzie co do ustawowych znamion czynu opartego na nieumyślności świadomej. W świetle art. 9 § 2 k.k. są wszelkie podstawy do przypisania czynu zabronionego popełnionego nieumyślnie na skutek owej nieumyślności świadomej. Nie oznacza to jednak możliwości przypisania przestępstwa nieumyślnego, wszak zależy to od tego, czy błąd ów był usprawiedliwiony, czy też nie, co przesuwa całe zagadnienie już w obszar winy.

Komisja Kodyfikacyjna Prawa Karnego przy Ministrze Sprawiedliwości przedstawiła 4 kwietnia 2013 r. projekt nowelizacji kodeksu karnego, w ramach którego zaproponowała gruntowne zmiany w obszarze art. 1 i 9 k.k., a także art. 28 $\S 1$ k.k. W projekcie tym przepisowi art. $28 \S 1$ k.k. nadano następujące brzmienie: „Nie popełnia przestępstwa nieumyślnego, kto działa w usprawiedliwionym błędzie co do okoliczności stanowiącej znamię przedmiotowe czynu zabronionego"50. W takim kształcie zmiana ta została przekazana do konsultacji społecznych.

Duży projekt nowelizacji kodeksu karnego, zawarty w druku sejmowym numer 2393, nie zawierał jednak zmian do art. 28 k.k. W trakcie prac nad zmianami do kodeksu karnego, które były w nim zawarte, Nadzwyczajna Komisja ds. Zmian w Kodyfikacjach w zakresie rządowego projektu ustawy o zmianie ustawy - Kodeks karny oraz niektórych innych ustaw, poselskiego projektu ustawy o zmianie ustawy - Kodeks karny, senackiego projektu ustawy o zmianie ustawy - Kodeks karny oraz ustawy - Kodeks karny wykonawczy przygotowała sprawozdanie (druk sejmowy 2981) z dnia 3 grudnia 2014 r. i zaproponowała dość osobliwe brzmienie art. $28 \S 1$ k.k. W świetle tej propozycji nie popełnia nieumyślnie czynu zabronionego, kto działa w usprawiedliwionym błędzie co do okoliczności stanowiącej znamię czynu zabronionego ${ }^{51}$.

Wskazane rozwiązanie miało na celu taką zmianę przepisu art. $28 \S 1$ k.k., aby nie powielał on skutków unormowania zawartego w art. 9 § 1 k.k., z którego a contrario wynikało, że w razie błędu w postaci nieświadomości ustawowego

48 T. Kaczmarek, J. Giezek, op. cit., s. 242.

49 Ł. Pohl, op. cit., s. 154-155.

50 Treść projektu przytoczona za M. Małeckim, op. cit., s. 39.

51 http://orka.sejm.gov.pl/Druki7ka.nsf/0/78577250CC25404CC1257DB100513E8A/\%24Fi le/2981.pdf (dostęp: 4.04.2017). 
znamienia pozytywnego albo urojenia negatywnego znamienia nie było możliwe przypisanie zamiaru. Zaproponowana zmiana była jednak wadliwa, albowiem nieumyślne popełnienie czynu zabronionego ze swej natury jest oparte na pewnych błędnych wnioskowaniach sprawcy (w przypadku nieumyślności świadomej jest to błędne prognozowanie przebiegu zdarzenia, a w przypadku nieumyślności nieświadomej jest to błędna diagnoza ${ }^{52}$ ). W przypadku błędu, który należy do istoty nieumyślności świadomej i nieświadomej, sprawca popełnia nieumyślnie czyn zabroniony, jeśli ustawa taką odmianę przewiduje, a problem sprowadza się do oceny tego błędu z punktu widzenia kryteriów usprawiedliwiających sprawcę $e^{53}$.

W literaturze podnosi się, że wskazana wyżej propozycja, zawarta w sprawozdaniu Nadzwyczajnej Komisji ds. Zmian w Kodyfikacjach z 3 grudnia 2014 r., w drodze wykładni a contrario mogła prowadzić do wniosku, że w przypadku gdy nie zachodził nieumyślny czyn zabroniony, konieczne było przypisanie czynu zabronionego popełnionego umyślnie ${ }^{54}$. Zgodzić się jednak należy z A. Grześkowiak, która stwierdza, że poprzez art. 9 § 1 k.k. a contrario można było dojść do konkluzji, że w przedstawionej sytuacji nie było mowy o przypisaniu czynu popełnionego umyślnie, albowiem jeśli — jak podnosi autorka — dla przypisania umyślności konieczne jest stwierdzenie świadomości ustawowych znamion, a usprawiedliwiony błąd zakłada, że świadomość ta jest ułomna, to brakuje podstaw dla przypisania umyślności ${ }^{55}$. Trafnie zatem podnosi M. Małecki, że w takim przypadku można było dojść do wniosku, iż sprawca nie popełnia ani czynu nieumyślnego, ani umyślnego ${ }^{56}$. Słusznie zrezygnowano więc z tej regulacji, skoro prima facie prowadziła do wniosku, którego z ontologicznych powodów nie można było zaakceptować 57 .

Na skutek poprawek Senatu zmieniono propozycję dotyczącą art. $28 \S 1$ k.k. (druk 3131; uchwała Senatu z 7 lutego 2015 r.), któremu nadano następujące brzmienie: „Nie popełnienia przestępstwa sprawca, który pozostaje w usprawiedliwionym błędzie co do okoliczności stanowiącej jego znamię"58. Komisja Nadzwyczajna do Spraw Zmian Kodyfikacyjnych na posiedzeniu w dniu 18 lutego 2015 r., którego przedmiotem były poprawki zaproponowane przez Senat, zaakceptowała propozycję zmiany art. $28 \S 1 \mathrm{k} . \mathrm{k}$. W takim kształcie został on uchwalony w ustawie z 20 lutego 2015 r. ${ }^{59}$

52 Bliżej na ten temat zob. T. Kaczmarek, J. Giezek, op. cit., s. 242.

53 Zob. M. Małecki, op. cit., s. 44.

54 Zob. np. A. Grześkowiak [w:] Kodeks karny. Komentarz, red. A. Grześkowiak, Warszawa 2015, s. 238.

55 Ibidem.

56 M. Małecki, op. cit., s. 45.

57 Ibidem.

58 http://orka.sejm.gov.pl/Druki7ka.nsf/0/713AF219F9DF9AFAC1257DE90038131D/\%24 File/3131.pdf (dostęp: 4.04.2017).

59 Dz.U. z 2015 r. poz. 396. 
Przyjęte rozwiązanie nie jest trafne z kilku powodów.

Po pierwsze, przepis art. $28 \S 1$ k.k. stanowi ogólnie o przestępstwie i czynie zabronionym, co prima facie może nasuwać wniosek, że dotyczy wszystkich kategorii czynów zabronionych, tj. zarówno umyślnych, jak i nieumyślnych. Tym samym ustawodawca powielił ten sam błąd, którym obarczone było pierwotne brzmienie tego unormowania, i objął nim także czyny zabronione umyślne. Tymczasem skutki błędu w postaci nieświadomości znamienia pozytywnego oraz urojenia znamienia negatywnego typu umyślnego z powodzeniem da się ocenić przez pryzmat art. $9 \S 1$ k.k. A zatem w drodze wykładni systemowej art. $9 \S 1$ k.k. i art. $28 \S 1$ k.k. konieczne jest zawężenie zakresu zastosowania tej ostatniej regulacji do czynów nieumyślnych. Jednakże z gramatycznego brzmienia przepisu art. $28 \S 1$ k.k. expressis verbis powinno to wynikać.

Po drugie, przepis w ogóle nie akcentuje tego, że w warunkach błędu co do ustawowych znamion może dochodzić do popełnienia nieumyślnego czynu zabronionego. Nadto uregulowanie zawarte w art. $28 \S 1$ k.k. po nowelizacji nie bierze pod uwagę tego, że natura błędu w przypadku nieumyślności nieświadomej jest nieco odmienna od błędu, który wiąże się immanentnie z nieumyślnością świadomą. W przypadku nieumyślności nieświadomej sprawca błędnie diagnozuje rzeczywistość, nie uświadamia sobie tego, że w ogóle popełnienia czyn zabroniony. Można zatem powiedzieć, że w tym przypadku błądzi co do wszystkich znamion, a także co do oceny prawnej swego zachowania. Błąd co do znamion zderza się tutaj z błędem co do bezprawności. Oznacza to, że jeśli błąd sprawcy oparty jest na błędnej diagnozie rzeczywistości, to sprawcy można również przypisać nieumyślnie popełniony czyn zabroniony. Ocena tej diagnozy przesuwa natomiast całe zagadnienie na płaszczyznę winy.

Po trzecie, nie wydaje się również trafna koncepcja art. $28 \S 1$ k.k., zaproponowana w projekcie Komisji Kodyfikacyjnej Prawa Karnego z 4 kwietnia 2013 r., zgodnie z którą nie popełnia przestępstwa nieumyślnego, kto działa w usprawiedliwionym błędzie co do okoliczności stanowiącej znamię przedmiotowe czynu zabronionego ${ }^{60}$. Taka stylizacja może także prowadzić do wniosku, że w przedstawionym przypadku należy przypisać sprawcy przestępstwo umyślne, skoro nie można przypisać mu przestępstwa nieumyślnego, co popada w kolizję z niekwestionowaną tezą, zgodnie z którą błąd co do znamion typu podstawowego wyłącza zamiar. Poza tym proponowane ujęcie nie akcentuje $\mathrm{w}$ dostateczny sposób pożądanego $\mathrm{w}$ świetle czystej koncepcji normatywnej winy odróżnienia winy od strony podmiotowej czynu zabronionego, wszak nie wynika z niego expressis verbis, że w warunkach takiego błędu sprawca popełnienia nieumyślnie czyn zabroniony, lecz nie jest możliwe przypisanie mu winy. Oczywiście, w drodze wykładni można dojść do wniosku, że przedstawione brzmienie art. $28 \S 1$ k.k. wskazuje na popełnienie czynu za-

60 Propozycja przytoczona przez A. Zolla, Prace nad nowelizacją części ogólnej kodeksu karnego, PiP 2012, nr 11, s. 9. 
bronionego nieumyślnie, albowiem jeżeli w świetle proponowanej zmiany sprawca nie popełniał nieumyślnego przestępstwa, to znaczy, że wnioskowanie takie miało miejsce na płaszczyźnie nieumyślnie popełnionego czynu zabronionego. Wydaje się jednak, że kwestia ta wymaga zdecydowanie wyraźniejszego podkreślenia.

Po czwarte, nie był uzasadniony powrót do propozycji ujęcia przepisu o błędzie co do faktu, zawartej w projekcie kodeksu karnego z 1990 r. ${ }^{61}$ Taka propozycja narażała się na ten sam zarzut, co pierwotny kształt art. $28 \S 1$ k.k., albowiem jeśli sprawca pozostawał w błędzie co do znamienia umyślnego typu zasadniczego, to nie można mu było przypisać przestępstwa umyślnego. Do takiego wnioskowania nie było jednak potrzebne nadanie przepisowi o błędzie wskazanego kształtu, wszak dało się wyprowadzić taki sam wniosek na podstawie ogólnego przepisu o umyślnym popełnieniu czynu zabronionego (art. $9 \S 1$ k.k.). Poza tym takie ujęcie sprzyjało wyodrębnieniu winy umyślnej i nieumyślnej, wszak mówiło o przestępstwie umyślnym a nadto o usprawiedliwieniu. Skoro ustawodawca stanął w kodeksie karnym na stanowisku czystej koncepcji normatywnej winy, która nie dzieli winy na umyślną i nieumyślną, to wprowadzanie takiego rozwiązania mogłoby być uznane za przejaw pewnej niekonsekwencji.

Wskazane spostrzeżenia prowadzą do wniosku, że przepis art. 28 § 1 k.k. powinien mieć następujące brzmienie: „Nie popełnia przestępstwa, kto dopuszcza się nieumyślnie czynu zabronionego pod wpływem usprawiedliwionego błędu co do okoliczności stanowiącej jego znamię". Przedstawiona propozycja ogranicza regulację dotyczącą usprawiedliwionego błędu co do faktu wyłączającego winę do typów nieumyślnych, wszak skutki błędu odnoszącego się do znamion typu umyślnego z powodzeniem daje się rozwiązać na podstawie art. $9 \S 1$ k.k. Ponadto akcentuje ona również odróżnienie winy od strony podmiotowej czynu zabronionego, która na gruncie czystej koncepcji normatywnej winy jest zasadą o fundamentalnym znaczeniu, albowiem z jednej strony mówi o nieumyślnym czynie zabronionym, z drugiej zaś stanowi o przestępstwie i usprawiedliwieniu. Wyraźnie wskazuje zatem na to, że czym innym jest wyczerpanie znamion nieumyślnego czynu zabronionego (rozstrzygane na podstawie art. 9 § 2 k.k.), a czym innym przypisywanie winy z powodu nieusprawiedliwienia błędu.

\section{The evolution of regulation of the mistake of fact in Polish criminal codes}

Summary

The subject of the article is the problem of the mistake of fact in Polish criminal law from historical perspective. It discusses the regulation concerning the mistake of fact in Polish criminal

61 Art. 27. „Nie popełnia przestępstwa umyślnego, kto dopuszcza się czynu pod wpływem błędu co do okoliczności stanowiącej znamię czynu zabronionego". 
codes of 1932, 1969, 1997 and shows the evolution of this structure. The author puts particular emphasis on the amendments to the section 28th of the Polish Criminal Code of 1997 which were proposed between 2013 and 2015. In the conclusion he criticizes the contemporary shape of the section and gives his own proposal for the amendment in this regulation which limits it only to non-intentional criminal acts and distinguishes properly guilty mind and mens rea which is essential in the light of the normative theory of guilt.

Keywords: criminal law, features of criminal, mistake of fact, the intention of the offense. 